\title{
The relationship between serum insulin-like growth factor-1 (IGF-1) concentration and reproductive performance, and genome-wide associations for serum IGF-1 in Holstein cows
}

\author{
M. Gobikrushanth, ${ }^{\star} \dagger$ D. C. Purfield,† M. G. Colazo, $\ddagger$ Z. Wang, ${ }^{*}$ S. T. Butler, $†$ and D. J. Ambrose ${ }^{*} \ddagger^{1}$ \\ *Department of Agricultural, Food and Nutritional Science, University of Alberta, Edmonton, AB, Canada, T6G 2P5 \\ $\ddagger$ Teagasc, Animal \& Grassland Research and Innovation Centre, Moorepark, Fermoy, Co. Cork, Ireland, P61 C996 \\ †Livestock Research and Extension Branch, Alberta Agriculture and Forestry, Edmonton, AB, Canada, T6H 5T6
}

\begin{abstract}
The objectives of this study were to determine (1) factors associated with serum concentration of insulinlike growth factor-1 (IGF-1); (2) the relationship between serum IGF-1 concentration during the first week postpartum and ovarian cyclicity status by 35 d postpartum (DPP); (3) an optimum serum IGF-1 concentration threshold predictive of pregnancy to first artificial insemination $(\mathrm{P} / \mathrm{AI})$, including its diagnostic values; (4) the associations among categories of serum IGF-1 concentration and reproductive outcomes $(\mathrm{P} /$ $\mathrm{AI}$ and pregnancy risk up to 150 and $250 \mathrm{DPP}$ ); and (5) single nucleotide polymorphisms (SNP) associated with phenotypic variation in serum IGF-1 concentration in dairy cows. Serum IGF-1 concentration was determined at $7( \pm 2.4 ; \pm$ standard error of the mean $)$ DPP in 647 lactating Holstein cows (213 primiparous, 434 multiparous) from 7 herds in Alberta, Canada. The overall mean, median, minimum, and maximum serum IGF-1 concentrations during the first week postpartum were $37.8( \pm 1.23), 31.0,20.0$, and $225.0 \mathrm{ng} / \mathrm{mL}$, respectively. Herd, age, parity, precalving body condition score, and season of blood sampling were all identified as factors associated with serum IGF-1 concentrations. Although serum IGF-1 concentration during the first week postpartum had no association with ovarian cyclicity status by $35 \mathrm{DPP}$ in primiparous cows, it was greater in cyclic than in acyclic multiparous cows (32.2 vs. $27.4 \mathrm{ng} / \mathrm{mL}$, respectively). The optimum serum IGF-1 thresholds predictive of P/AI were $85.0 \mathrm{ng} / \mathrm{mL}$ (sensitivity $=31.9 \%$; specificity $=89.1 \%$ ) and 31.0 $\mathrm{ng} / \mathrm{mL}$ (sensitivity $=45.5 \%$; specificity $=66.9 \%$ ) for primiparous and multiparous cows, respectively. When cows were grouped into either high or low IGF-1 categories (greater or less than or equal to $85.0 \mathrm{ng} / \mathrm{mL}$ for
\end{abstract}

Received February 2, 2018.

Accepted May 31, 2018.

${ }^{1}$ Corresponding author: divakar.ambrose@gov.ab.ca primiparous cows and greater or less than or equal to $31.0 \mathrm{ng} / \mathrm{mL}$ for multiparous cows, respectively), primiparous cows with high IGF-1 had 4.43 times greater odds of $\mathrm{P} / \mathrm{AI}$ and a tendency for higher pregnancy risk up to 150 DPP than those with low IGF-1, but not up to $250 \mathrm{DPP}$. Likewise, multiparous cows with high IGF-1 had 1.61 times greater odds of P/AI than those with low IGF-1. Pregnancy risk up to 150 and 250 DPP, however, did not differ between IGF-1 categories in multiparous cows. Moreover, 37 SNP across 10 Bos taurus autosomes were associated with variation in serum IGF-1 concentration, and 4 previously identified candidate genes related to fertility that were in linkage disequilibrium with some of these SNP were also identified.

Key words: fertility traits, genome-wide association study, reproductive efficiency

\section{INTRODUCTION}

Insulin-like growth factor-1 is a low-molecular-weight peptide, mainly produced by liver (Lund et al., 1986), that controls the growth and differentiation of different cell types in the body through activation of cell cycle (Rechler and Nissley 1990). Hence, it plays a key role in the control of postnatal growth, mammary gland development, lactation, and reproduction in dairy cows (Lammers et al., 1999; Jiang and Lucy, 2001; Renaville et al., 2002; Butler 2003).

During the early postpartum period, cows are in a state of negative energy balance (NEB) due to high milk yield and low DMI (Butler and Smith 1989), where the growth hormone (GH)-IGF-1 axis is uncoupled due to downregulation of GH receptors in liver (McGuire et al., 1995; Kobayashi et al., 1999). This, in turn, is associated with decreased IGF-1 and increased GH concentrations to promote the action of GH on lipolysis and gluconeogenesis to favor the milk production (Lucy et al., 2001). Insulin-like growth factor-1 is also essential for reproduction by acting synergistically 
with gonadotropins (Lucy et al., 1992; Spicer et al., 1993; Beam and Butler 1999). Therefore, partitioning of nutrients mainly toward milk production, indicated by high NEB /low IGF-1 concentration, jeopardizes the fertility of dairy cows (Butler 2000).

As a potential fertility trait, circulating concentration of IGF-1 has been identified as having high variability, moderate heritability, and positive associations with fertility (see review by Velazquez et al., 2008). Zulu et al. (2002) and Moyes (2004) reported that postpartum concentrations of circulating IGF-1 were highly variable among dairy cows. Although 18 to $48 \%$ of this variation was attributable to genetic variation (Grochowska et al., 2001; Stirling et al., 2008; Hayhurst et al., 2009), the remaining variation was influenced by other factors such as postpartum nutrient intake, BW and BCS at calving, and parity in cattle (Ciccioli et al., 2003; Pushpakumara et al., 2003; Wathes et al., 2003, respectively). Previous studies also reported that cows with high circulating IGF-1 concentrations postpartum had greater pregnancy to first AI (P/AI) than those with low circulating IGF-1 (Pushpakumara et al., 2003; Taylor et al., 2004; Kawashima et al., 2007; Patton et al., 2007; Falkenberg et al., 2008).

Although previous studies reported a positive association between circulating IGF-1 concentration and fertility, most of them were primarily based on multiparous cows only (Lucy et al., 1992; Beam and Butler 1997; Pushpakumara et al., 2003; Kawashima et al., 2007; Patton et al., 2007; Falkenberg et al., 2008). Taylor et al. (2004) used a combination of 177 primiparous and 142 multiparous cows to evaluate the association between circulating IGF-1 concentration and P/AI; however, the sensitivity and specificity (diagnostic values) for optimum IGF-1 threshold predictive of P/AI were not reported. Falkenberg et al. (2008) reported that determining circulating IGF-1 concentration at early postpartum $[1,4,10,20$ or $40 \mathrm{~d}$ postpartum (DPP)] had a very limited diagnostic value in predicting P/AI in multiparous cows, but such evaluations are unknown in primiparous cows.

Recent evidence suggest that despite similar milk yield, cows with high genetic merit for fertility were able to maintain better body condition and had greater circulating IGF-1 concentration than cows with poor genetic merit for fertility (Cummins et al., 2012; Moore et al., 2014). This finding suggests the existence of potential genetic differences for circulating IGF-1 among cows that are genetically divergent in fertility. Consequently, the identification of SNP associated with phenotypic variation in circulating IGF-1 concentrations and the subsequent incorporation of these SNP within genomic evaluations may help to accurately identify females with high circulating IGF-1 to enhance fertility in dairy cows. The main hypotheses of the present study were that the threshold serum IGF-1 concentration predictive of $\mathrm{P} / \mathrm{AI}$ would differ between primiparous and multiparous cows, and SNP associated with phenotypic variation in serum IGF-1 would be identified.

Our objectives were to determine (1) the factors associated with serum concentration of IGF-1, (2) the association between serum IGF-1 concentration during the first week postpartum and ovarian cyclicity status by $35 \mathrm{DPP}$, (3) an optimum serum IGF-1 threshold predictive of $\mathrm{P} / \mathrm{AI}$ and its diagnostic values for primiparous and multiparous cows, (4) the associations among categories of serum IGF-1 concentration and reproductive outcomes $(\mathrm{P} / \mathrm{AI}$ and pregnancy risk up to 150 and $250 \mathrm{DPP}$ ) for primiparous and multiparous cows, and (5) SNP associated with phenotypic variation in serum IGF-1 concentrations through a genome-wide association study (GWAS).

\section{MATERIALS AND METHODS}

\section{Animals and Management}

This study was conducted in the Dairy Research and Technology Centre, University of Alberta, with 6 commercial dairy herds located in Alberta between November 2014 and November 2015. Animals were housed and cared for in accordance with the requirements of Canadian Council on Animal Care (2009). Cows were fed a TMR (primary ingredients were barley or corn silage, alfalfa silage, alfalfa hay, and concentrates) formulated according to NRC (2001) and had ad libitum access to potable water. Cows from 4 herds were subjected to GnRH-based synchronization protocols and inseminated without estrus detection for the first and subsequent AI (timed AI), whereas, cows from 3 herds were inseminated at detected estrus.

\section{Blood Sampling and Determination of Serum Concentrations of IGF-1}

Blood samples were collected at (mean \pm SD) 7 $\pm 2.4 \mathrm{DPP}$ (hereafter referred to as the first week postpartum) from 647 lactating Holstein cows (213 primiparous, 434 multiparous) from a coccygeal blood vessel using evacuated Vacutainer (Becton Dickinson and Company, Franklin Lakes, NJ) clot-activator tubes (serum tubes) for serum IGF-1 determination and anticoagulant $\mathrm{K}_{2}$ EDTA coated tubes (EDTA tubes) for genotyping. Blood samples were collected after morning milking when cows had just been offered fresh feed. After collection, serum tubes were left undisturbed for about $2 \mathrm{~h}$ to allow clot formation, centrifuged at 1500 $\times g$ for 20 min at $4^{\circ} \mathrm{C}$ and the serum was harvested and 
frozen at $-20^{\circ} \mathrm{C}$ until assayed for IGF-1. The EDTA tubes containing whole blood were frozen at $-20^{\circ} \mathrm{C}$ until processed for genotyping. Serum concentrations (ng/ $\mathrm{mL}$ ) of IGF-1 were determined at Endocrine Lab Services, University of Saskatchewan, Saskatoon, Canada, using a solid-phase, enzyme-labeled chemiluminescent immunometric assay (Immulite, Siemens, Tarrytown, NY) in singlicate, with every fifth sample run in duplicate, as previously described (Elmlinger et al., 2005). The samples were diluted 1:10 with the pretreatment solution provided with the kit. The intra-assay coefficient of variation was $7.8 \%$ for low reference samples $($ mean $=75.0 \mathrm{ng} / \mathrm{mL})$ and $7.2 \%$ for high reference samples $($ mean $=236.5 \mathrm{ng} / \mathrm{mL}$ ), and the sensitivity of the assay was $20 \mathrm{ng} / \mathrm{mL}$. When an IGF-1 concentration fell below the assay sensitivity $(<20.0 \mathrm{ng} / \mathrm{mL})$ it was considered as $10.0 \mathrm{ng} / \mathrm{mL}$.

\section{Determination of Variables}

The age (years) of the cow was calculated by subtracting the date of birth from the date of serum IGF-1 determination. The BCS was determined between 1 and 2 wk before to the estimated calving date (hereafter referred to as precalving BCS) and again between 4 and 6 wk after calving (hereafter referred to as postcalving BCS) on a 1 to 5 scale system measured in increments of 0.25 units $(1=$ thin, $5=$ fat $)$ as previously described (Edmonson et al., 1989). The ovarian cyclicity status (cyclic $=$ presence of at least 1 corpus luteum; acyclic $=$ absence of a corpus luteum) was determined between 28 and $35 \mathrm{DPP}$ (hereafter referred to as by $35 \mathrm{DPP}$ ) using transrectal ultrasonography. The data on reproductive outcomes and 305-d mature-equivalent (MEq) milk yield were retrieved at the end of the production cycle using DairyComp 305 herd management software (Valley Agricultural Software, Tulare, CA).

\section{Genotyping, Quality Control, and Imputation}

The DNA extraction was performed on blood samples drawn from a subset of 589 lactating Holstein cows using the Qiagen BioSprint 96 DNA (3840) Kit blood and tissue protocol (Qiagen, Toronto, ON). The DNA samples were normalized and genotyped according to the Illumina Infinium Ultra protocol (Illumina, San Diego, $\mathrm{CA}$ ) and markers were scored on the Bovine Geneseek Genomic Profiler 26K Beadchip (Neogen Inc., Lincoln, $\mathrm{NE}$ ) at Delta Genomics (Edmonton, AB, Canada). The beadchips were scanned using the Illumina HiScan (Illumina) and the raw data were processed and exported using Genome Studio 2.0 software according to the Genome Studio Framework User Guide (Illumina) based on selection criteria of at least $95 \%$ animal call rate.
Genotype quality control was performed using PLINK v1.09 (Purcell et al., 2007). After excluding SNP with an unknown, Y chromosomal, or mitochondrial position, SNP with a call rate $<90 \%$, minor allele frequency (MAF) $<0.01$, and those that deviated significantly from Hardy-Weinberg equilibrium $\left(P \leq 10^{-6}\right)$ were also removed. All animals had a genotype call rate $>90 \%$ and 19,896 SNP remained after edits. To increase the density of SNP panel for GWAS, imputation to the Illumina Bovine High Density (HD) beadchip was performed using FImpute2 (Sargolzaei et al., 2014). Imputation was completed using a 2-step approach whereby the 589 animals were first imputed to the Illumina BovineSNP50 chip using a reference population of 3,532 Irish Holstein-Friesian BovineSNP50-genotyped animals, and subsequently imputed to HD using a reference population of 974 Irish Holstein-Friesian HDgenotyped animals. After imputation, all 589 cows had 636,471 SNP with a MAF $>0.01$ for analysis.

\section{Statistical Analyses}

Data were analyzed using SAS version 9.4 (SAS Institute Inc., Cary, NC). The descriptive statistics and normality for serum IGF-1 concentration were first determined in all 647 cows (213 primiparous, 434 multiparous) using the UNIVARIATE procedure.

The differences in serum IGF-1 concentration (dependent continuous variable) among herd (A, B, C, D, E, $\mathrm{F}$, and $\mathrm{G}$ ), age $(2,3,4$, and $\geq 5 \mathrm{yr}$ ), parity (primiparous and multiparous), precalving BCS (categorized as high and low BCS, $>3.00$ and $\leq 3.00$, respectively), and season of blood sampling [fall (September, October, and November), spring (March, April, and May), summer (June, July, and August), and winter (December, January, and February)] were determined in a subset of 460 cows (152 primiparous cows and 308 multiparous cows) that had complete data available on all explanatory variables studied. The nonparametric Kruskal-Wallis test was employed because of the non-normal distribution for serum IGF-1 concentration. Pairwise comparisons for levels within each significant factor were performed using the Dunn-Bonferroni post-hoc test.

The proportion of cows cyclic by $35 \mathrm{DPP}$ for primiparous $(\mathrm{n}=152)$ and multiparous $(\mathrm{n}=308)$ cows was compared using chi-squared analysis using the FREQ procedure in the subset of 460 cows. The differences in serum IGF-1 concentration during the first week postpartum in cows stratified by ovarian cyclicity status (cyclic vs. acyclic) by 35 DPP were determined within primiparous $(\mathrm{n}=152)$ and multiparous $(\mathrm{n}=$ 308) cows by the nonparametric Kruskal-Wallis test. The results from the nonparametric Kruskal-Wallis test were based on Wilcoxon scores (rank sums) estimated 

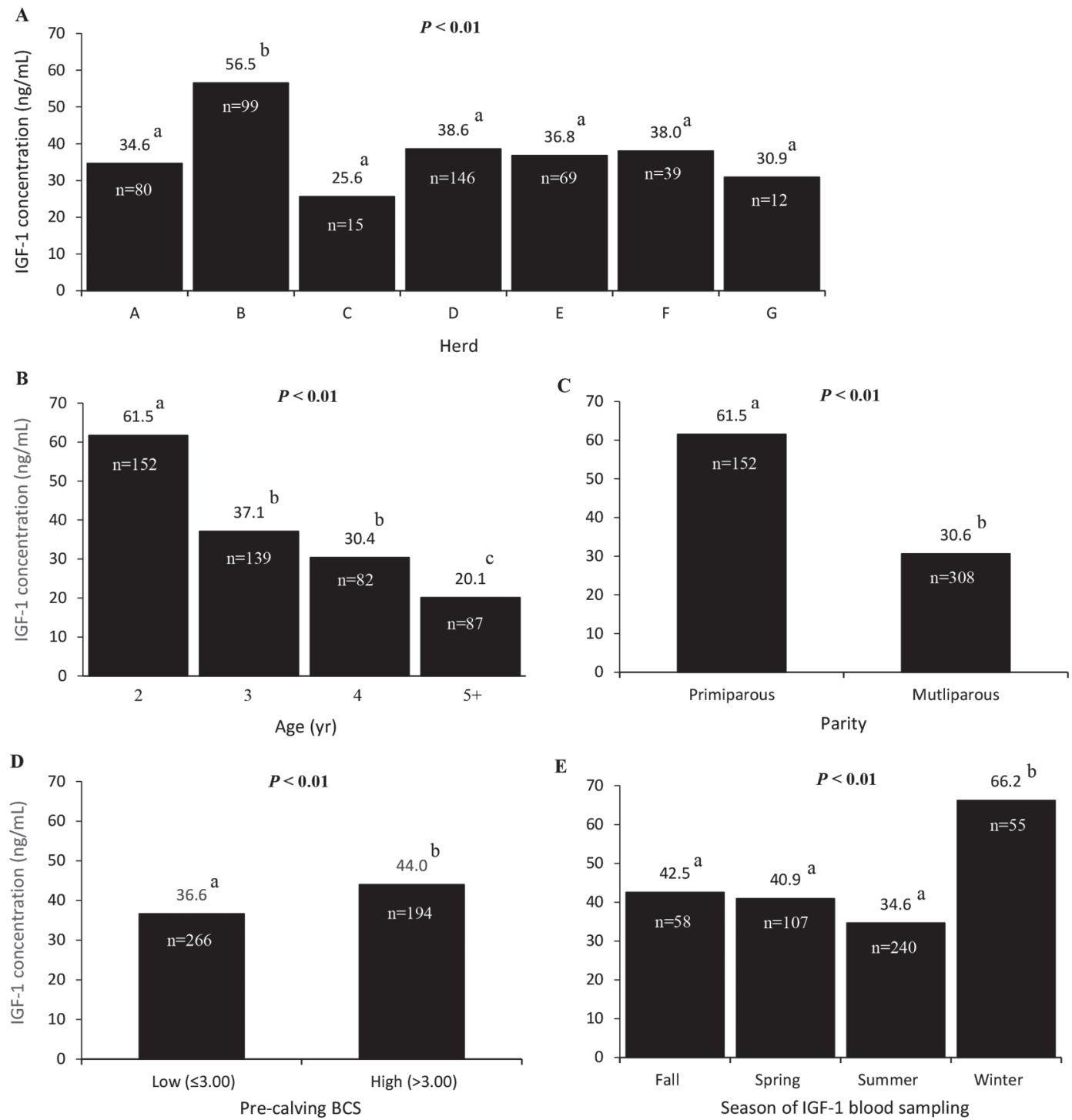

Figure 1. Mean concentrations of serum IGF-1 $(\mathrm{ng} / \mathrm{mL})$ at $7( \pm 2.4)$ d postpartum among herd (A), age (B), parity (C), precalving BCS (D), and season of IGF-1 blood sampling (E) in a subset of 460 lactating Holstein cows. Different letters (a-c) within the same category differ $(P<0.05)$

for the variable serum IGF-1; however, the mean values for serum IGF-1 concentration were reported in the related figures (Figure 1 and 2) for ease of interpretation.

Out of 647 cows enrolled, the relationship between $\mathrm{P} / \mathrm{AI}$ (binomial outcome) and serum IGF-1 concentration (predictor continuous variable) during the first week postpartum was first evaluated, separately for primiparous $(\mathrm{n}=186)$ and multiparous $(\mathrm{n}=377)$ cows that had P/AI data $(\mathrm{n}=573)$ available, by logistic regression analysis using the LOGISTIC procedure. The serum IGF-1 concentration predictive of P/AI, including specificity and sensitivity, was determined using receiver operating characteristic (ROC) curve analysis separately for primiparous and multiparous cows. The
ROC curves analyze sensitivity and 1 - specificity. Sensitivity is the proportion of cows above the optimum IGF-1 threshold diagnosed pregnant to first AI, and specificity is the proportion of cows below the optimum IGF-1 threshold diagnosed as not pregnant to first AI. The optimum serum IGF-1 concentration threshold was chosen based on the highest Youden's J statistic index. The significance of the optimum serum IGF-1 concentration threshold was determined based on the area under the curve (AUC), where the AUC ranged from 0.50 to 1.00 , with AUC of 0.50 considered noninformative and the AUC of 1.00 considered perfect as previously described (Swets, 1988). Thereafter, cows were classified into either high or low IGF-1 categories 


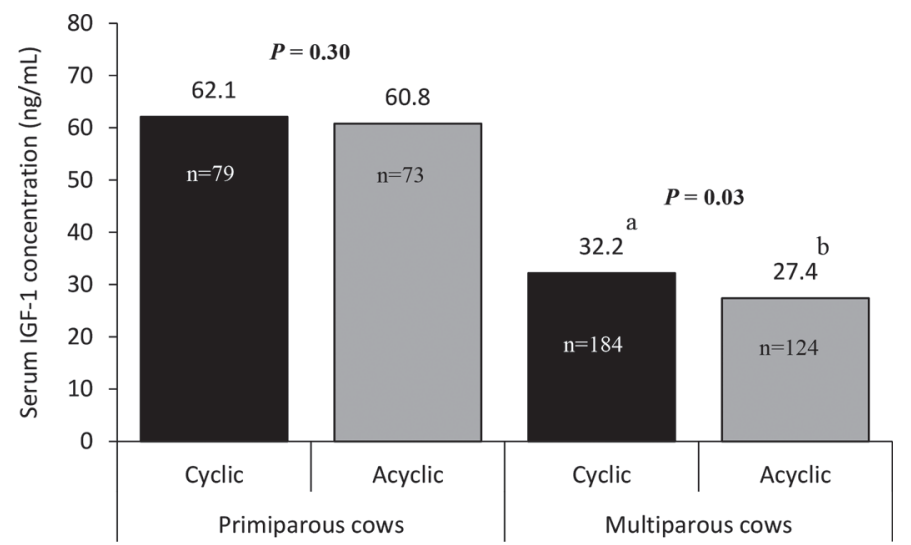

Figure 2. Mean serum concentrations of IGF-1 $(\mathrm{ng} / \mathrm{mL})$ at 7 $( \pm 2.4)$ d postpartum stratified by cyclicity status (black bar $=$ cyclic and gray bar = acyclic) determined by ultrasonography (based on presence of a CL) at $35 \mathrm{~d}$ postpartum in primiparous $(\mathrm{n}=152)$ and multiparous $(\mathrm{n}=308)$ cows. Different letters $(\mathrm{a}, \mathrm{b})$ within the same category differed $(P<0.05)$.

$(>$ or $\leq$ ), separately for primiparous and multiparous cows, based on the optimum serum IGF-1 concentration threshold determined by the ROC curve analysis.

The association among categories of serum IGF-1 (high and low IGF-1), herd (A, B, C, D, E, F, and G), type of AI (inseminated at detected estrus and timed $\mathrm{AI}$ ), ovarian cyclicity status by $35 \mathrm{DPP}$ (cyclic and acyclic), precalving BCS (categorized as high and low BCS, $>3.00$ and $\leq 3.00$, respectively), postcalving BCS (categorized as high and low BCS, $>2.75$ and $\leq 2.75$, respectively), season of IGF-1 blood sampling [fall (September, October, and November), spring (March, April, and May), summer (June, July, and August), and winter (December, January, and February)], 305d MEq milk yield (categorized as high and low 305-d MEq milk yield, based on the mean 305-d MEq milk yield within each herd), and P/AI was analyzed, separately for primiparous $(\mathrm{n}=152)$ and multiparous $(\mathrm{n}=$ 308) cows, using the GLIMMIX procedure in the subset of 460 cows that had complete data available on the explanatory variables studied. The model specifications included a binomial distribution and logit function and an option to retrieve odds ratios and their confidence limits. The $\mathrm{P} / \mathrm{AI}$ was initially modeled against all of the aforementioned categorical variables and their interactions. As none of the interactions were significant, they were removed from the final model.

The differences in intervals from calving to pregnancy risk up to 150 and 250 DPP between categories of serum IGF-1, separately for primiparous $(\mathrm{n}=152)$ and multiparous $(\mathrm{n}=308)$ cows, were evaluated using the Kaplan-Meier survival analysis (LIFETEST procedure). The results from Kaplan-Meier survival analysis were confirmed by a cox proportional hazard model
(PHREG procedure). Significant differences were reported if $P \leq 0.05$ and considered to be a tendency if $P$ $>0.05$ and $\leq 0.10$.

\section{GWAS for Circulating IGF-1 Concentrations}

Whole genome association analysis was performed in genome-wide complex trait analysis (Yang et al., 2011) using a mixed linear model based association based on the leave-one-chromosome-out method (Yang et al., 2014). The following model was used

$$
\mathrm{y}=\mu+\mathbf{b x}+\mathrm{g}^{-}+\mathrm{e},
$$

where $y$ is the IGF-1 category classified separately for primiparous and multiparous cows as previously described; $\mu$ is the overall mean; $\mathbf{b}$ is a vector of fixed effects including herd, parity, precalving BCS, season of blood sampling, and the additive effect of the candidate SNP tested for association; $\mathbf{x}$ is the incidence matrix for the parameters $\mathrm{b} ; \mathrm{g}^{-}$is the accumulated polygenic effect of all SNP except those on the chromosome where the candidate SNP is located; and e is the residual. False discovery rate control was performed using the Benjamini-Hochberg method using a false discovery rate of 0.05. Gene search was completed using Ensembl (http://ensembl.org/) and NCBI map viewer (https:/ /www.ncbi.nlm.nih.gov/genome/gdv/) on the University of Maryland assembly of Bos taurus 3.1 genome build (UMD 3.1, College Park, MD). The relative roles of nearest candidate genes were searched using Bovine Genome Database (http://bovinegenome.org/).

\section{RESULTS AND DISCUSSION}

The overall mean $( \pm$ SEM $)$, median, minimum, and maximum serum IGF-1 concentrations during the first week postpartum were $37.8( \pm 1.23), 31.0,20.0$, and $225.0 \mathrm{ng} / \mathrm{mL}$. To the best of our knowledge, this is the first study to examine the relationship between several risk factors (e.g., herd, age, parity, BCS, and season of blood sampling for IGF-1) and serum IGF-1 concentration in a single large experiment comprising both primiparous and multiparous cows (Figure 1). It has been previously reported that circulating IGF-1 concentrations were significantly greater in primiparous than multiparous cows (Wathes et al., 2003; Taylor et al., 2004; Grimard et al., 2013). Similarly, the results from the current study indicated that circulating concentration of IGF-1 gradually declined with age (Figure 1B), and was approximately 2 -fold greater in primiparous cows than in multiparous cows (Figure 1C). The above findings collectively indicate the requirement for 


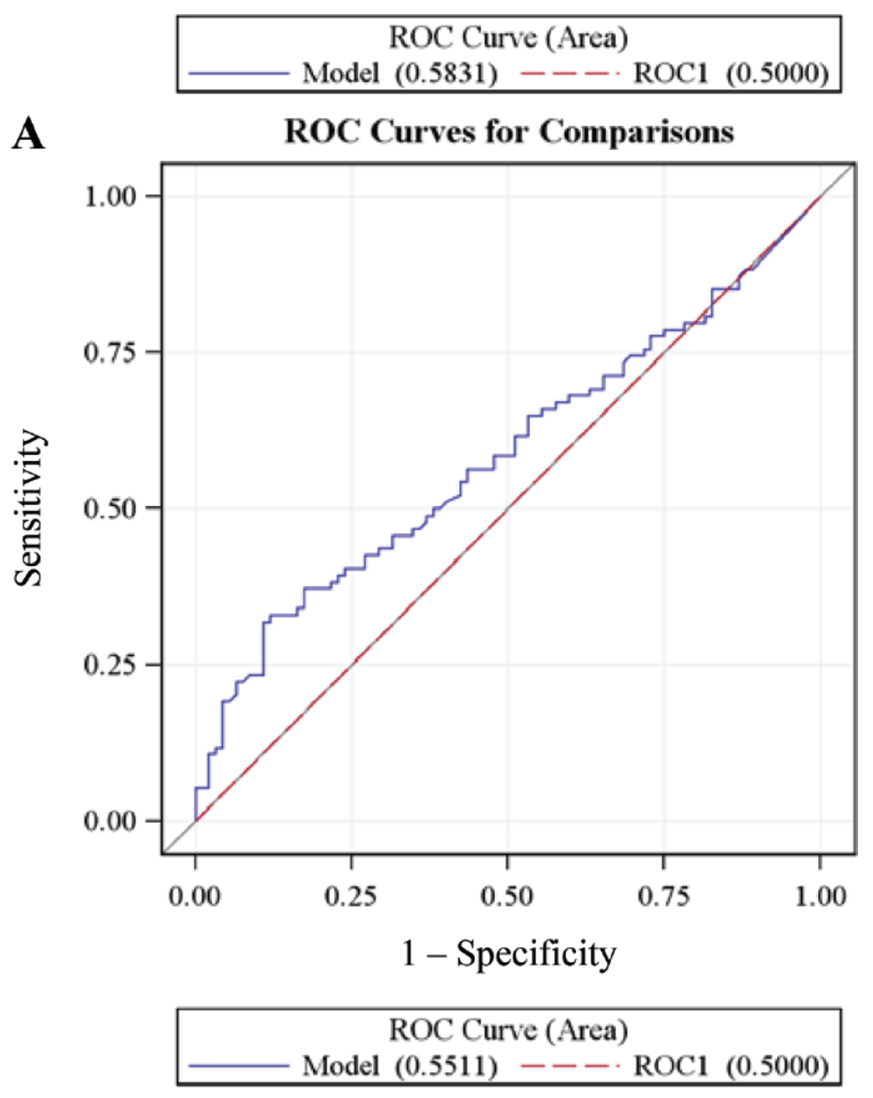

B

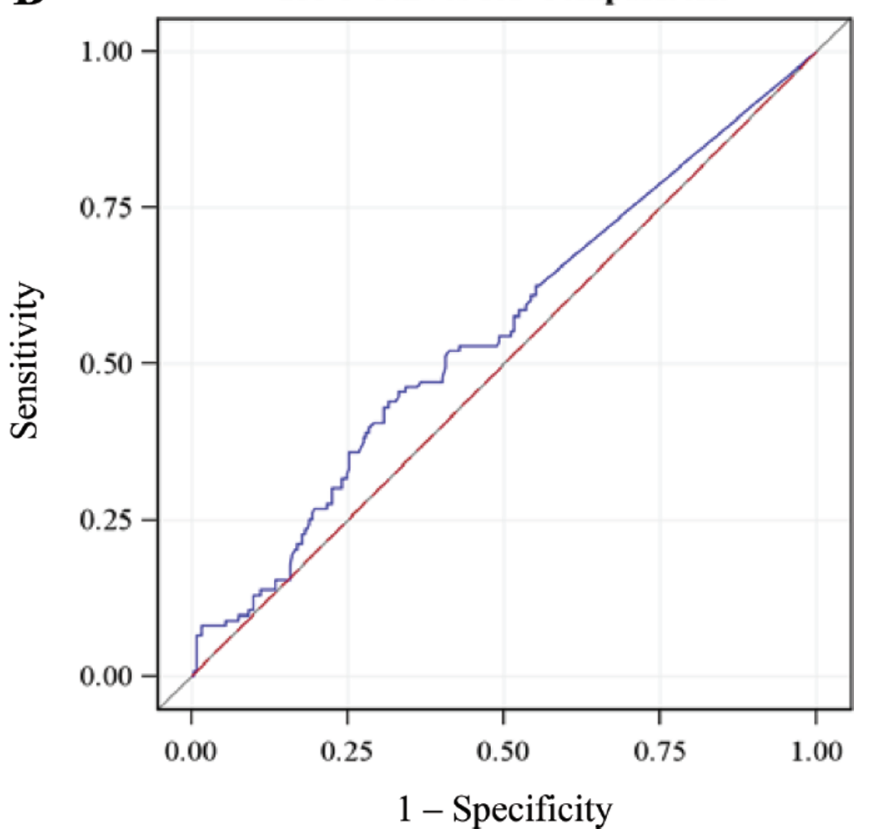

Figure 3. The receiver operating characteristic (ROC) curve analysis for serum IGF-1 concentration at $7( \pm 2.4)$ d postpartum predictive of pregnancy to first $\mathrm{AI}(\mathrm{P} / \mathrm{AI})$ in primiparous $(\mathrm{A} ; \mathrm{n}=186)$ and multiparous $(\mathrm{B} ; \mathrm{n}=377)$ cows. The optimum serum IGF-1 concentration threshold predictive of $\mathrm{P} / \mathrm{AI}$ was $85.0 \mathrm{ng} / \mathrm{mL}$ for primiparous cows (sensitivity of $31.9 \%$ and specificity of $89.1 \% ; P=0.04$ ) and $31.0 \mathrm{ng}$ / $\mathrm{mL}$ for multiparous cows (sensitivity of $45.5 \%$ and specificity of $66.9 \%$; $P=0.09)$. Color version available online. high circulating IGF-1 in young cows to support their body growth until they reach physical maturity (Kerr et al., 1991).

In the current study, serum IGF-1 concentration during the first week postpartum was greater in cows with high precalving BCS than in cows with low precalving BCS (Figure 1D), which is in agreement with previous reports (Pushpakumara et al., 2003; Meikle et al., 2004; Cummins et al., 2012). Interestingly, serum concentration of IGF-1 was greater in samples collected during winter than in the other seasons (Figure 1E). High serum IGF-1 concentration reported during winter in the current study supports the initial observation of Spicer et al. (1990), who reported an inverse relationship between ambient temperature and circulating IGF-1 in 11 lactating multiparous cows. It is plausible that high energy requirements in winter to meet increased metabolic rate (Young, 1981) stimulated greater DMI, and thereby resulted in greater secretion of IGF-1 during winter than rest of the seasons. The serum concentra-
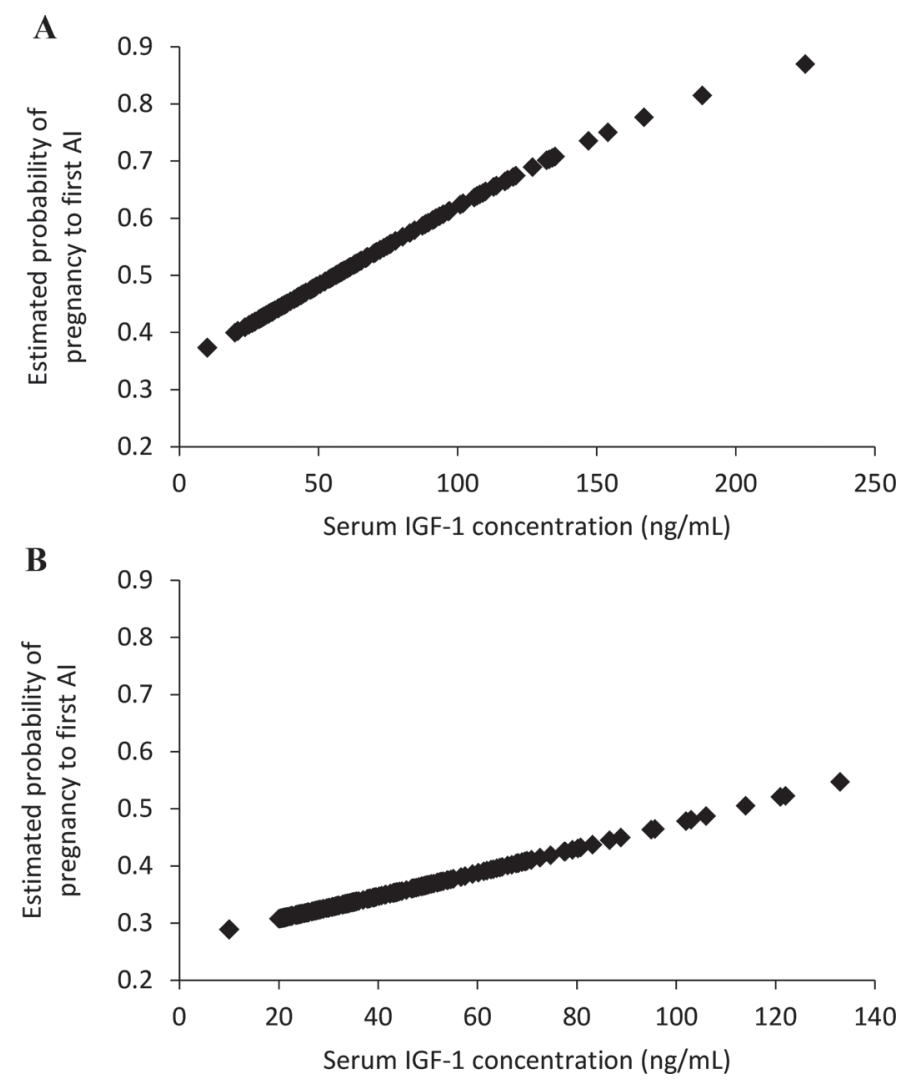

Figure 4. The odds of estimated probability of pregnancy to first AI (P/AI) plotted against serum IGF-1 concentrations at $7( \pm 2.4)$ $\mathrm{d}$ postpartum in primiparous $(\mathrm{A} ; \mathrm{n}=186)$ and multiparous $(\mathrm{B} ; \mathrm{n}=$ 377) cows. For every 1-ng/mL increase in serum IGF-1 concentration, the odds of estimated probability of $\mathrm{P} / \mathrm{AI}$ increased by $1.1 \%$ in primiparous cows $(P<0.01)$ and $0.9 \%$ in multiparous cows $(P=0.05)$, respectively. 
tion of IGF-1 was quite similar among herds except for herd B (Figure 1A). The greater IGF-1 concentration observed for herd B compared with other herds was likely due to approximately $50 \%$ of cows from this herd being sampled during winter months. In addition to the risk factors studied (e.g., herd, age, parity, BCS, and season of blood sampling), the differences among cows in their feed intake and energy status on the day of blood sampling for serum IGF-1 may also have contributed to the variation observed in serum IGF-1 concentration during the first week postpartum in the current study.
Overall, $57 \%$ of the cows were cyclic by 35 DPP, which agrees with a recent report from our laboratory (Bruinjé et al., 2017), wherein 53\% of dairy cows had commenced their ovarian cyclicity by 35 DPP based on progesterone concentrations determined through an automated in-line milk analysis system. A higher proportion of multiparous cows tended to be cyclic by 35 DPP than primiparous cows ( 60 vs. $52 \% ; P=0.07$ ), despite primiparous cows having 2-fold greater concentrations of serum IGF-1 than multiparous cows. Insulin-like growth factor-1 acts synergistically with gonadotropins to promote early postpartum ovarian follicular growth

Table 1. The associations among categories of IGF-1, herd, type of AI, ovarian cyclicity status, precalving BCS, postcalving BCS, season, 305-d mature-equivalent (MEq) milk yield, and pregnancy to first AI (P/AI) in 152 primiparous cows

\begin{tabular}{|c|c|c|c|c|}
\hline Variable & $\begin{array}{l}\text { Pregnancy to first } \\
\text { AI, \% (no./no.) }\end{array}$ & $\begin{array}{l}\text { Odds ratio } \\
\text { estimates }\end{array}$ & $95 \% \mathrm{CI}$ & $P$-value \\
\hline \multicolumn{5}{|c|}{$\overline{\text { IGF-1 } \text { category }^{1}(\mathrm{ng} / \mathrm{mL})}$} \\
\hline High-IGF-1 (>85.0) & $74.3(28 / 38)$ & 4.43 & $(1.51-12.96)$ & $<0.01$ \\
\hline Low-IGF-1 $(\leq 85.0)$ & $44.2(45 / 114)$ & Referent & & \\
\hline \multicolumn{5}{|l|}{ Herd } \\
\hline $\mathrm{A}$ & $60.9(14 / 23)$ & - & - & 0.10 \\
\hline $\mathrm{B}$ & $45.7(16 / 35)$ & - & - & \\
\hline $\mathrm{C}$ & $0.0(0 / 5)$ & - & - & \\
\hline $\mathrm{D}$ & $56.6(30 / 53)$ & - & - & \\
\hline $\mathrm{E}$ & $26.3(5 / 19)$ & - & - & \\
\hline $\mathrm{F}$ & $44.4(8 / 15)$ & - & - & \\
\hline G & $0.0(0 / 2)$ & Referent & & \\
\hline \multicolumn{5}{|l|}{ Type of $\mathrm{AI}^{2}$} \\
\hline IDE & $40.4(19 / 47)$ & 0.64 & $(0.32-1.29)$ & 0.21 \\
\hline TAI & $51.4(54 / 105)$ & Referent & & \\
\hline \multicolumn{5}{|l|}{ Ovarian cyclicity status $^{3}$} \\
\hline Cyclic & $46.8(37 / 79)$ & 1.22 & $(0.48-3.11)$ & 0.67 \\
\hline Acyclic & $49.3(36 / 73)$ & Referent & & \\
\hline \multicolumn{5}{|l|}{ Precalving $\mathrm{BCS}^{4}$} \\
\hline High $(>3.00)$ & $42.4(28 / 66)$ & 0.59 & $(0.19-1.83)$ & 0.35 \\
\hline Low $(\leq 3.00)$ & $52.3(45 / 86)$ & Referent & & \\
\hline \multicolumn{5}{|l|}{ Postcalving $\mathrm{BCS}^{4}$} \\
\hline High $(>2.75)$ & $52.1(37 / 71)$ & 2.27 & $(0.74-6.97)$ & 0.15 \\
\hline Low $(\leq 2.75)$ & $44.4(36 / 81)$ & Referent & & \\
\hline \multicolumn{5}{|l|}{ Season $^{5}$} \\
\hline Fall & $53.8(7 / 13)$ & 1.91 & $(0.18-19.9)$ & 0.78 \\
\hline Spring & $52.6(20 / 38)$ & 0.73 & $(0.13-4.24)$ & \\
\hline Summer & $45.1(37 / 82)$ & 0.92 & $(0.17-5.03)$ & \\
\hline \multirow{2}{*}{\multicolumn{5}{|c|}{ 305-d MEq milk yield ${ }^{6}(\mathrm{~kg})$}} \\
\hline & & & & \\
\hline $\operatorname{High}(>10,179)$ & $31.6(24 / 76)$ & 0.21 & $(0.09-0.51)$ & $<0.01$ \\
\hline Low $(\leq 10,179)$ & $64.5(49 / 76)$ & Referent & & \\
\hline
\end{tabular}

${ }^{1}$ IGF-1 categories were based on the optimum serum IGF-1 threshold $(85.0 \mathrm{ng} / \mathrm{mL})$ predictive of pregnancy to first $\mathrm{AI}(\mathrm{P} / \mathrm{AI})$ in primiparous cows determined using receiver operating characteristic curve analysis (Figure 4a).

${ }^{2}$ Cows were inseminated at detected estrus (IDE) or timed-AI (TAI) following synchronization of ovulation.

${ }^{3}$ Ovarian cyclicity status by 35 days postpartum (DPP); cows were determined as cyclic: presence of at least 1 corpus luteum and acyclic: absence of a corpus luteum by 35 DPP using transrectal ultrasonography.

${ }^{4}$ Categories of precalving BCS (determined between 1 and 2 wk before calving) and postcalving BCS (determined between 4 and 6 wk after calving) were based on precalving BCS of 3.00 and postcalving BCS of 2.75.

${ }^{5}$ Season of IGF-1 blood sampling; categorized as [fall (September, October, and November), spring (March, April, and May), summer (June, July, and August), and winter (December, January, and February)].

${ }^{6}$ Cows were categorized as high or low if 305-d MEq milk yield was $>$ or $\leq$ the mean within each herd, respectively. Overall mean across herds was $10,179 \mathrm{~kg}$. 
and ovulation in dairy cows (Lucy et al., 1992; Spicer et al., 1993; Beam and Butler 1997). For example, circulating IGF-1 concentrations were reported to be 40 to $50 \%$ greater during first 2 wk postpartum in multiparous cows having an ovulatory dominant follicle compared with cows that had a nonovulatory dominant follicle (Beam and Butler 1997). Similarly, Patton et al. (2007) showed that circulating concentrations of IGF-1 during first $2 \mathrm{wk}$ postpartum were negatively associated with commencement of luteal activity in multiparous cows. Although serum IGF-1 concentration determined during the first week postpartum was not associated with ovarian cyclicity status by 35 DPP in primiparous cows (cyclic vs. acyclic; 62.1 vs. $60.8 \mathrm{ng} / \mathrm{mL}$ ), it was greater in cyclic than acyclic multiparous cows (32.2 vs. $27.4 \mathrm{ng} / \mathrm{mL}$; Figure 2). The lack of association reported herein between circulating IGF-1 concentration and ovarian cyclicity status in primiparous cows might be attributable to partitioning of nutrients, mainly toward growth and milk production, than supporting other biological functions (Wathes et al., 2007).

Taylor et al. (2004) suggested that multiparous cows with circulating IGF-1 concentration $<25.0 \mathrm{ng} / \mathrm{mL}$ were less likely to conceive to first AI, and therefore it is cost-effective to delay the first service in those cows until the circulating IGF-1 has increased to a concen-

Table 2. The associations among categories of IGF-1, herd, type of AI, ovarian cyclicity status, precalving BCS, postcalving BCS, season, 305-d mature-equivalent (MEq) milk yield, and pregnancy to first AI (P/AI) in 308 multiparous cows

\begin{tabular}{|c|c|c|c|c|}
\hline Variable & $\begin{array}{c}\text { Pregnancy to } 1 \text { st AI, } \\
\% \text { (no./no.) }\end{array}$ & $\begin{array}{l}\text { Odds ratio } \\
\text { estimates }\end{array}$ & $95 \% \mathrm{CI}$ & $P$-value \\
\hline \multicolumn{5}{|c|}{$\overline{\text { IGF-1 } \text { category }^{1}(\mathrm{ng} / \mathrm{mL})}$} \\
\hline High-IGF-1 (>31.0) & $40.9(52 / 127)$ & 1.61 & $(0.95-2.73)$ & 0.08 \\
\hline Low-IGF-1 $(\leq 31.0)$ & $29.8(54 / 181)$ & Referent & & \\
\hline \multicolumn{5}{|l|}{ Herd } \\
\hline $\mathrm{A}$ & $45.6(26 / 57)$ & 0.50 & $(0.12-2.15)$ & 0.25 \\
\hline B & $32.8(21 / 64)$ & 0.20 & $(0.04-1.08)$ & \\
\hline $\mathrm{C}$ & $30.0(3 / 10)$ & 0.30 & $(0.04-2.19)$ & \\
\hline $\mathrm{D}$ & $25.8(24 / 93)$ & 0.27 & $(0.06-1.28)$ & \\
\hline $\mathrm{E}$ & $30.0(15 / 50)$ & 0.26 & $(0.06-1.09)$ & \\
\hline $\mathrm{F}$ & $45.8(11 / 24)$ & 0.58 & $(0.12-2.85)$ & \\
\hline $\mathrm{G}$ & $60.0(6 / 10)$ & Referent & & \\
\hline \multicolumn{5}{|l|}{ Type of $\mathrm{AI}^{2}$} \\
\hline IDE & $37.6(44 / 117)$ & 1.25 & $(0.77-2.03)$ & 0.36 \\
\hline TAI & $32.5(62 / 191)$ & Referent & & \\
\hline \multicolumn{5}{|c|}{ Ovarian cyclicity status ${ }^{3}$} \\
\hline Cyclic & $37.5(69 / 184)$ & 1.13 & $(0.63-2.02)$ & 0.68 \\
\hline \multirow{2}{*}{\multicolumn{5}{|c|}{ Precalving BCS ${ }^{4}$}} \\
\hline & & & & \\
\hline High $(>3.00)$ & $39.1(50 / 128)$ & 0.97 & $(0.51-1.86)$ & 0.93 \\
\hline Low $(<3.00)$ & $31.1(56 / 180)$ & Referent & & \\
\hline \multicolumn{5}{|l|}{ Postcalving $\mathrm{BCS}^{4}$} \\
\hline High $(>2.75)$ & $42.1(48 / 114)$ & 1.28 & $(0.67-2.43)$ & 0.46 \\
\hline Low $(\leq 2.75)$ & $29.9(58 / 194)$ & Referent & & \\
\hline \multicolumn{5}{|l|}{ Season $^{5}$} \\
\hline Fall & $40.0(18 / 45)$ & 0.55 & $(0.13-2.33)$ & 0.55 \\
\hline Spring & $27.5(19 / 69)$ & 0.42 & $(0.13-1.40)$ & \\
\hline Summer & $34.1(54 / 158)$ & 0.53 & $(0.16-1.77)$ & \\
\hline Winter & $41.6(15 / 36)$ & Referent & & \\
\hline \multicolumn{5}{|c|}{ 305-d MEq milk yield ${ }^{6}(\mathrm{~kg})$} \\
\hline High $(>11,542)$ & $36.9(55 / 149)$ & 1.09 & $(0.63-1.87)$ & 0.76 \\
\hline Low $(\leq 11,542)$ & $32.1(51 / 159)$ & Referent & & \\
\hline
\end{tabular}

${ }^{1}$ IGF-1 categories were based on the optimum serum IGF-1 threshold $(31.0 \mathrm{ng} / \mathrm{mL})$ that tended to predict pregnancy to first $\mathrm{AI}(\mathrm{P} / \mathrm{AI})$ in multiparous cows using receiver operating characteristic curve analysis (Figure $4 \mathrm{~b})$.

${ }^{2}$ Cows were inseminated at detected estrus (IDE) or timed-AI (TAI) following synchronization of ovulation.

${ }^{3}$ Ovarian cyclicity status by 35 days postpartum (DPP); cows were determined as cyclic: presence of at least 1 corpus luteum and acyclic: absence of a corpus luteum by 35 DPP using transrectal ultrasonography.

${ }^{4}$ Categories of precalving BCS (determined between 1 and 2 wk before calving) and postcalving BCS (determined between 4 and 5 wk after calving) were based on precalving BCS of 3.00 and postcalving BCS of 2.75.

${ }^{5}$ Season of IGF-1 blood sampling; categorized as [fall (September, October, and November), spring (March, April, and May), summer (June, July, and August), and winter (December, January, and February)].

${ }^{6}$ Cows were categorized as high or low if 305-d MEq milk yield was $>$ or $\leq$ the mean within each herd, respectively. Overall mean across herds was $11,542 \mathrm{~kg}$. 
tration $\geq 50 \mathrm{ng} / \mathrm{mL}$. Those authors did not, however, report the sensitivity and specificity of using $25.0 \mathrm{ng} /$ $\mathrm{mL}$ as an optimum threshold predictive of $\mathrm{P} / \mathrm{AI}$. In contrast, Falkenberg et al. (2008) concluded that determining circulating IGF-1 concentration at either 1,4 , 10,20 , or $40 \mathrm{~d}$ postpartum has very limited diagnostic value to predict $\mathrm{P} / \mathrm{AI}$ in multiparous cows. Hence, the optimum IGF-1 concentration threshold that is predictive of $\mathrm{P} / \mathrm{AI}$, including its diagnostic values, is unknown in primiparous cows. In the current study, the optimum serum IGF-1 threshold predictive of $\mathrm{P} /$ AI was $85.0 \mathrm{ng} / \mathrm{mL}$ for primiparous cows (Figure $3 \mathrm{~A}$ ) and $31.0 \mathrm{ng} / \mathrm{mL}$ for multiparous cows (Figure $3 \mathrm{~B}$ ). The optimum serum IGF-1 threshold established for multiparous cows in the present study $(31.0 \mathrm{ng} / \mathrm{mL})$ was comparable to $25.0 \mathrm{ng} / \mathrm{mL}$ threshold reported by Taylor et al. (2004). Primiparous cows, however, required greater serum IGF-1 threshold concentration ( $~ 50.0$ $\mathrm{ng} / \mathrm{mL}$ more) for optimal prediction of $\mathrm{P} / \mathrm{AI}$ than multiparous cows. Nevertheless, the sensitivities of these optimum serum IGF-1 concentration thresholds were moderate in both primiparous and multiparous cows (31.9 and $45.5 \%$, respectively) despite relatively higher specificities (89.1 and 66.9\%, respectively). Therefore, the routine measurement of early postpartum circulating IGF-1 concentrations to predict P/AI and thereby to manage low IGF-1 cows with enhanced nutritional strategies or even to delay the first service to improve $\mathrm{P} / \mathrm{AI}$ seems neither practical nor economically justifiable in either primiparous or multiparous cows.

Positive associations between circulating IGF-1 concentrations and $\mathrm{P} / \mathrm{AI}$ have been reported in lactating dairy cows (Pushpakumara et al., 2003; Taylor et al., 2004; Patton et al., 2007; Falkenberg et al., 2008). In a recent study, Grimard et al. (2013) reported that the likelihood of fertility (proportion of cows pregnant to first and second AI; $\mathrm{n}=32$ ) tended to increase with increasing circulating IGF-1 concentration in dairy cows. However, that report did not statistically quantify the magnitude of increment and did not account for parity. In the current study, for every $1-\mathrm{ng} / \mathrm{mL}$ increase in serum IGF-1 concentration, the odds of estimated probability of $\mathrm{P} / \mathrm{AI}$ increased by 1.1 and $0.9 \%$ for primiparous and multiparous cows, respectively (Figure $4 \mathrm{~A}$ and $\mathrm{B})$. Moreover, primiparous and multiparous cows in the high IGF-1 category had 4.43 and 1.61 times greater odds of $\mathrm{P} / \mathrm{AI}$ than cows in the low IGF-1 category (Table 1 and 2). These findings collectively indicate a positive association between high circulating IGF-1 concentration and increased P/AI in dairy cows. The effect of IGF-1 on early pregnancy outcomes may be mediated by its endocrine effects on follicular growth, granulosa cell mitogenesis, granulosa and thecal cell steroid production, and reproductive tract and endometrial gland secretions to support embryonic growth (Wathes et al., 1998; Robinson et al., 2000; Zulu et al., 2002; Pushpakumara et al., 2002; Fenwick et al., 2008).

Even though the likelihood of pregnancy by 150 DPP was greater in the high IGF-1 category than in low IGF-1 category within primiparous cows, it did not differ between IGF-1 categories within multiparous cows (Figure 5). The likelihood of pregnancy by 250 DPP did not differ between high and low IGF-1 categories within both primiparous [hazard ratio $=1.40$ (confidence interval $=0.93-2.10) ; P=0.11]$ and multiparous cows $[$ hazard ratio $=0.98$ (confidence interval $=0.75-1.27)$;

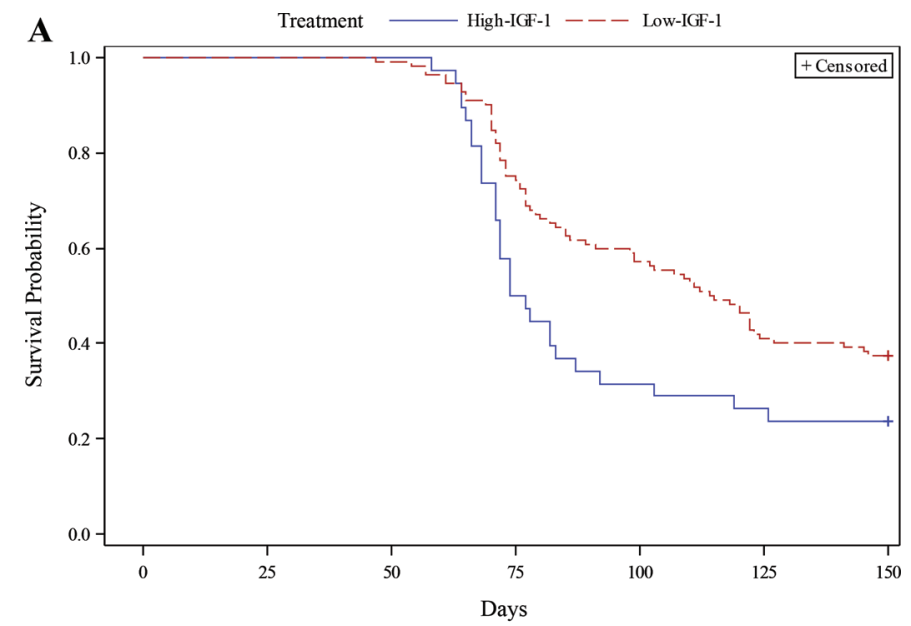

B

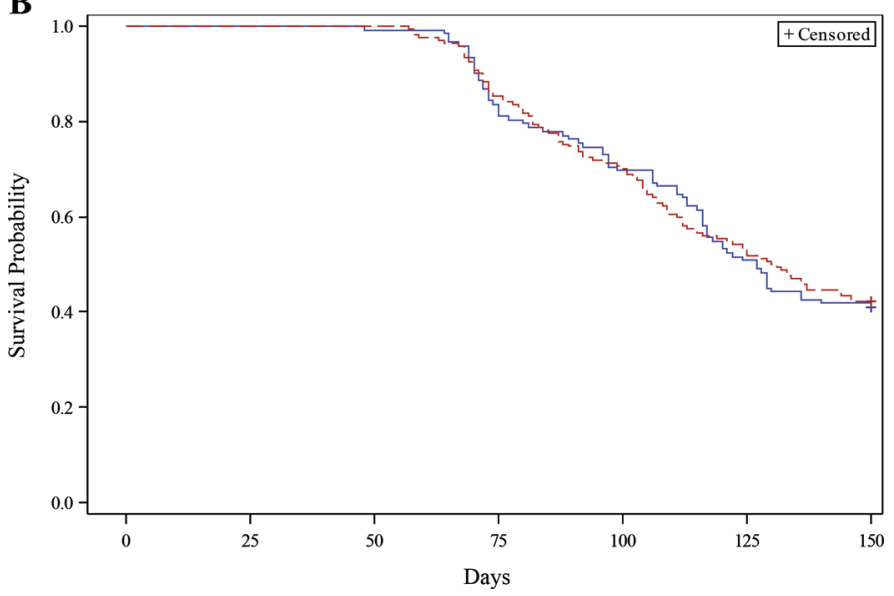

Figure 5. Kaplan-Meier survival curve that illustrates the proportion of primiparous (A) and multiparous (B) cows (by IGF-1 category) pregnant by $150 \mathrm{~d}$ postpartum (DPP). In primiparous, the hazard of pregnancy by $150 \mathrm{DPP}$ was greater [hazard ratio $=1.69$ (confidence interval $=1.10-2.61) ; P=0.02]$ for high IGF-1 category cows ( $>85.0 \mathrm{ng} / \mathrm{mL} ; \mathrm{n}=38$; solid line) than those in the low IGF-1 category ( $\leq 85.0 \mathrm{ng} / \mathrm{mL} ; \mathrm{n}=114$; broken line). In multiparous, however, the hazard of pregnancy by $150 \mathrm{DPP}$ did not differ [hazard ratio $=$ 1.02 (confidence interval $=0.75-1.39) ; P=0.88]$ between cows in the high IGF-1 ( $>31.0 \mathrm{ng} / \mathrm{mL} ; \mathrm{n}=52$; solid line) and low IGF-1 categories $(\leq 31.0 \mathrm{ng} / \mathrm{mL} ; \mathrm{n}=54$; broken line). Color version available online. 
$P=0.87$. Although Falkenberg et al. (2008) found no association between circulating concentration of IGF1 at 1,4 or $10 \mathrm{DPP}$ and proportion of multiparous cows pregnant within $200 \mathrm{DPP}$, they reported that the proportion of multiparous cows pregnant within 200 DPP was smaller for those with low circulating IGF-1 concentrations than those with high circulating IGF-1 concentrations at $40 \mathrm{DPP}$. These results collectively indicate that IGF-1 concentration based on a single blood sample collected during the first week postpartum has no predictive value on reproductive performance beyond first service in dairy cows.

Although GWAS evaluating the relationship between SNP in the IGF1 gene and fertility is recent interest (Mullen et al., 2011; Nicolini et al., 2013), studies unravelling SNP associated with phenotypic variation in circulating IGF-1 concentrations are lacking in dairy cows. In the current study, no SNP remained significantly associated with serum IGF-1 concentration after adjustment for multiple testing. However, $37 \mathrm{SNP}$ of suggestive significance in this study $(P<0.0001)$ were identified across 10 Bos taurus autosomes (BTA; 1, 2, 4, 6, 8, 9, 16, 23, and 26; Figure 6). Genomic regions associated with serum IGF-1 concentration and putative candidate genes within $250 \mathrm{~kb}$ up and downstream of the strongest association were listed in Table 3. Of these $37 \mathrm{SNP}$, those that were in linkage disequilibrium with previously identified candidate genes related to fertility were discussed below. It is noteworthy, however, that no SNP were identified to be in linkage dis- equilibrium with the candidate gene $I G F 1$ from BTA 5 , which was likely because the regulation of circulating IGF-1 concentrations may not be primarily controlled by the IGF1 gene. For example, Schneider et al., (2013) studied the effects of GH receptor (GHR) AluI polymorphism on the reproductive performance of Holstein cows and reported that cows with $2(-/-)$ GHR AluI alleles had the highest serum IGF-1 concentration and shortest calving to conception interval compared with those cows with either $1(-/+)$ or $0(+/+)$ alleles for GHR AluI polymorphism.

We identified 4 candidate genes (ARHGEF26, HGF, $G C$, and $P T P R K$ ) that were in linkage disequilibrium with SNP related to phenotypic variation in serum IGF-1 that have also been previously reported to influence fertility in mice (Uehara et al., 1995) or cattle (Huang et al., 2010; Minten et al., 2013; Killeen et al., 2014). None of these genes, however, is known to regulate serum IGF-1 concentrations in dairy cows. Thus, the results presented herein should be interpreted with caution. The candidate gene ARHGEF26 is located within $215 \mathrm{~kb}$ upstream of the lead SNP rs110526526 (at $114.2 \mathrm{Mb}$ ) on BTA 1 and encodes the member of the rho guanine nucleotide exchange factor family. In a recent study, Killeen et al. (2014) reported ARHGEF as one among several differentially expressed endometrial genes during the mid-luteal phase of the estrous cycle between beef heifers ranked as either high or low fertility, and identified as functionally related to cell morphology, inflammatory response, and lipid metabolism

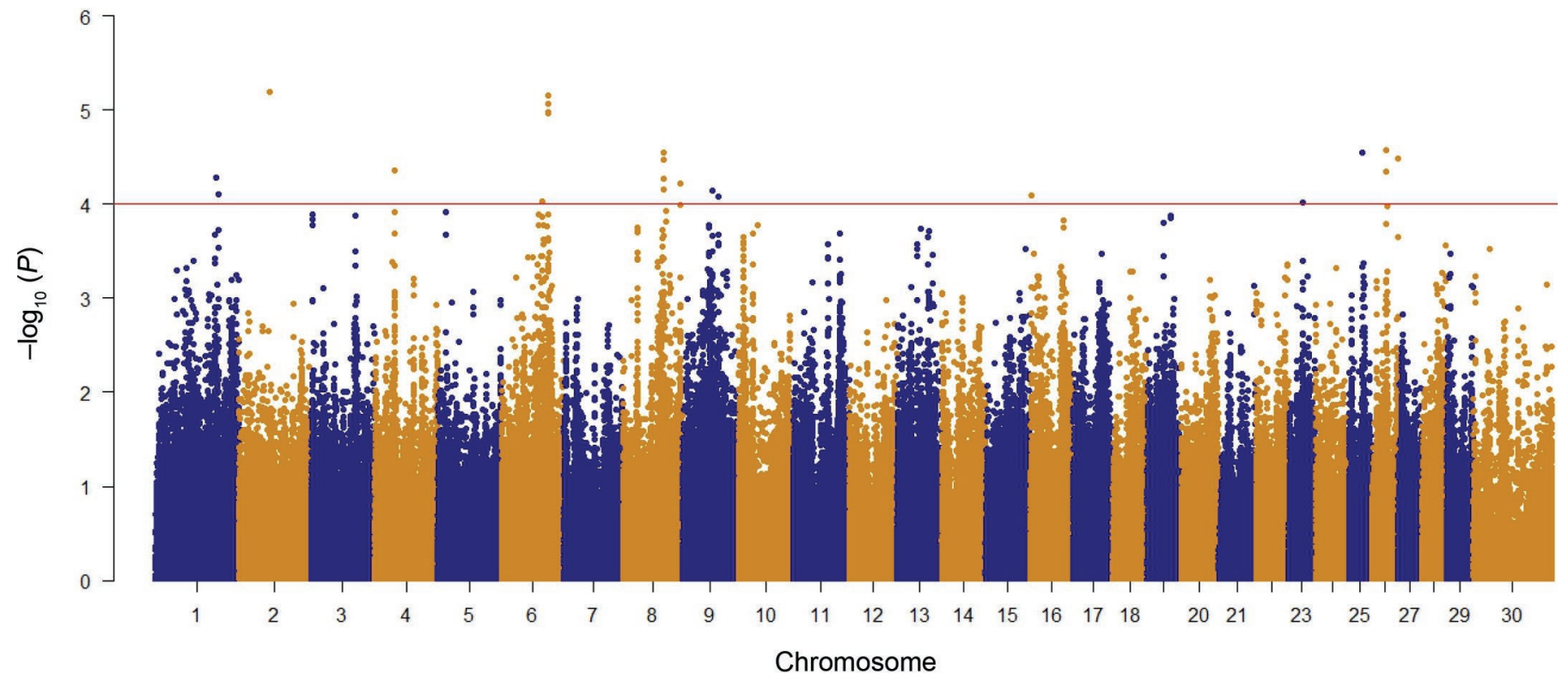

Figure 6. Manhattan plot of the genome-wide association study for serum IGF-1 concentration in Holstein cows. The horizontal line represents all single nucleotide polymorphisms with a $P$-value $<0.0001$ identified across 10 BTA $(1,2,4,6,8,9,16,23,25$, and 26). Color version available online. 
GOBIKRUSHANTH ET AL.

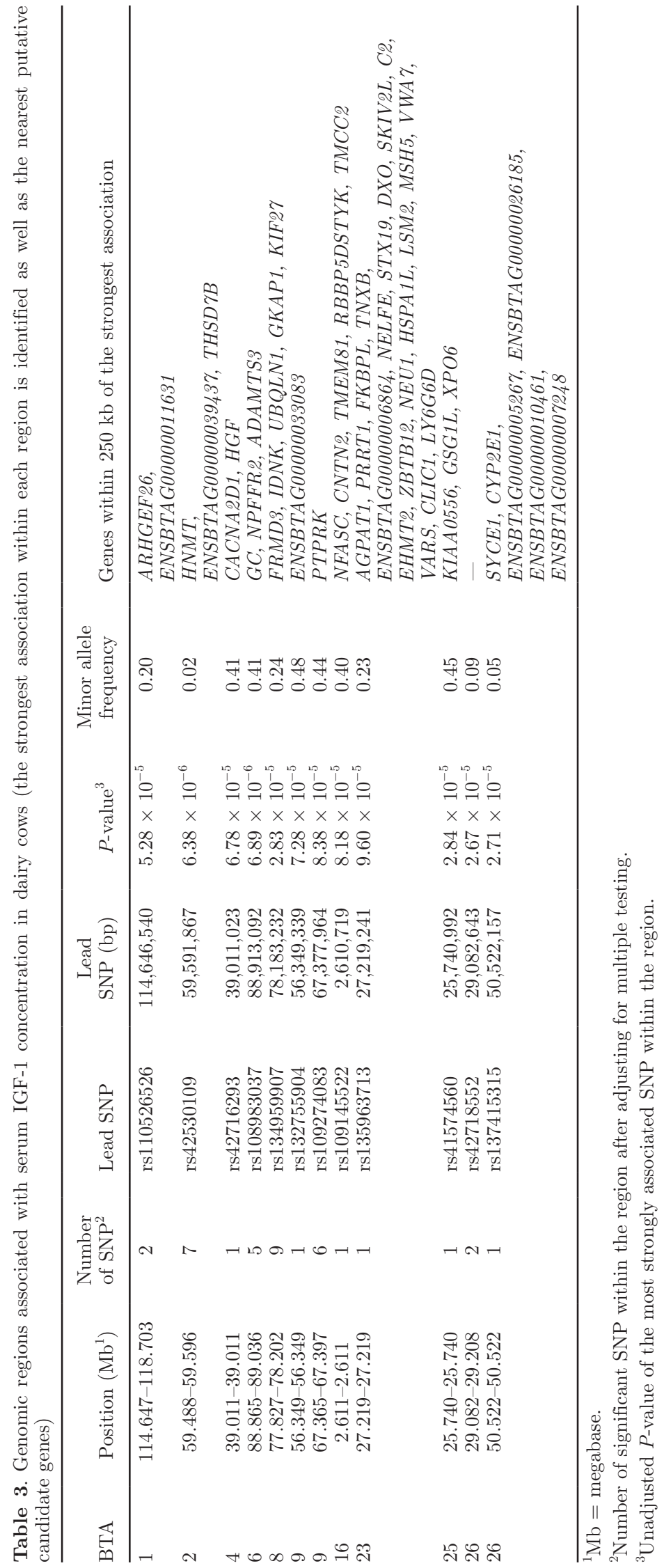


using the ingenuity pathway analysis. The candidate gene $H G F$ (hepatic growth factor) is located $105 \mathrm{~kb}$ downstream of the lead SNP rs42716293 (at 39.1 Mb) on BTA 4, and is involved in cell growth, cell motility, and morphogenesis in numerous cell and tissue types. In this regard, Uehara et al. (1995) showed that homozygous mutant mice embryos for $H G F$ gene had severely impaired placentas with markedly reduced numbers of labyrinthine trophoblast cells and died before birth.

Moreover, the candidate gene $G C$ (group-specific component) is located $217 \mathrm{~kb}$ upstream of the lead SNP rs108983037 (at 88.6 Mb) on BTA 6. The protein encoded by this gene belongs to albumin gene family and binds to vitamin $\mathrm{D}$ and its plasma metabolites to transport them to target tissues (Cooke and Haddad 1989), where vitamin D has been shown to be essential for endometrial functions and pregnancy success in humans and animal models (Luk et al., 2012). In a recent study, Minten et al. (2013) demonstrated that the gene $G C$ was differentially expressed in the endometrium of infertile, subfertile, and highly fertile beef heifers at d 14 of the estrous cycle. Finally, the lead SNP rs109274083 on BTA 9 is an intronic variant within the candidate gene PTPRK, which encodes the member of the protein tyrosine phosphatase family and is known to regulate a variety of cellular processes including cell growth and differentiation. Huang et al. (2010) showed that PTPRK was downregulated by at least 4 fold in in vitro-derived degenerative embryos compared with blastocysts in cattle. Perhaps, greater P/AI reported for cows with high circulating IGF-1 could at least partially supported by the roles of aforementioned candidate genes that are in genomic regions identified for variation in circulating IGF-1 concentrations in addition to the direct effect of circulating IGF-1 on fertility. Moreover, it is important to recognize that fertility is a highly polygenic trait under the control of thousands of SNP effects (Minozzi et al., 2013), and these candidate genes are some of many that contribute marginally to the phenotypic variance.

In summary, (1) serum IGF-1 concentration during the first week postpartum was associated with herd, age, parity, BCS at precalving, and season of blood sampling. Likewise, (2) cyclic multiparous cows had greater serum IGF-1 concentration during the first week postpartum compared with acyclic multiparous cows. (3) The optimum serum IGF-1 thresholds predictive of $\mathrm{P} / \mathrm{AI}$, separately for primiparous and multiparous cows, were identified; however, the reliability of IGF-1 as a predictor of $\mathrm{P} / \mathrm{AI}$ is low due to its moderate sensitivity. (4) Both primiparous and multiparous cows with high circulating IGF-1 concentration had greater P/ AI than those with low circulating IGF-1. Finally, (5)
37 SNP associated with phenotypic variation in serum IGF-1 concentrations across 10 chromosomes (BTA $1,2,4,6,8,9,16,23,25$, and 26), and 4 previously identified candidate genes related to fertility that were in linkage disequilibrium with some of these SNP, were identified. Despite identification of SNP, the collective findings suggest that a single measurement of serum IGF-1 concentration during the first week postpartum might not be an accurate predictor of fertility given the many factors that influence reproductive success in dairy cows.

\section{ACKNOWLEDGMENTS}

This project was financially supported in part by Growing Forward 2, a federal-provincial-territorial initiative (Research Opportunities and Innovation - Internal Initiatives Projects \# DA7642064 and MC4234670; Alberta Agriculture and Forestry, Edmonton, Canada). We thank Alberta Livestock and Meat Agency (Grant \#2016F056R) and Alberta Milk, both in Edmonton, Canada, for supporting parts of this research. M. Gobikrushanth is a recipient of the Teagasc-University of Alberta Walsh Fellowship sponsored by Alberta Innovates Biosolutions, Edmonton, Canada. The authors thank Amir Behrouzi and Courtney Felton of Livestock Research and Extension Branch, Alberta Agriculture and Forestry (Edmonton, Canada,) Irene LopezHelguera, visiting scientist from University of Lleida (Lleida, Spain), and Tianfu Yang, Tony Bruinjé, Patricia Dutra, Rohanna Wang and Ashley L'Hirondelle of University of Alberta for their assistance during the study. The authors thank the staff of the Dairy Research and Technology Centre, University of Alberta, the owners of the commercial dairy farms (Breevliet Ltd., Wetaskiwin, Canada; Enterprises Lavoie Inc., St. Isidore, Canada; Five Star Cattle Company, Lacombe, Canada; Tuxedo Farms, Westlock, Canada; Vanden Dool Farms, Picture Butte, Canada; Yoke Farm Ltd., Westlock, Canada), and the herd veterinarians for their cooperation and participation.

\section{REFERENCES}

Beam, S. W., and W. R. Butler. 1997. Energy balance and ovarian follicle development prior to the first ovulation postpartum in dairy cows receiving three levels of dietary fat. Biol. Reprod. 56:133-142.

Beam, S. W., and W. R. Butler. 1999. Effects of energy balance on follicular development and first ovulation in postpartum dairy cows. J. Reprod. Fertil. Suppl. 54:411-424.

Bruinjé, T. C., M. G. Colazo, M. Gobikrushanth, and D. J. Ambrose. 2017. Relationships among early postpartum luteal activity, parity, and insemination outcomes based on in-line milk progesterone profiles in Canadian Holstein cows. Theriogenology 100:32-41.

Butler, W. R. 2000. Nutritional interactions with reproductive performance in dairy cattle. Anim. Reprod. Sci. 60-61:449-457. 
Butler, W. R. 2003. Energy balance relationships with follicular development, ovulation and fertility in postpartum dairy cows. Livest. Prod. Sci. 83:211-218.

Butler, W. R., and R. D. Smith. 1989. Interrelationship between energy balance and postpartum reproductive function in dairy cattle. J. Dairy Sci. 72:767-783.

Canadian Council on Animal Care. 2009. CCAC Guidelines on: The Care and Use of Farm Animals in Research, Teaching and Testing. Accessed Sep. 6, 2014. http://ccac.ca/Documents/Standards/ Guidelines/Farm_Animals.pdf

Ciccioli, N. H., R. P. Wettemann, L. J. Spicer, C. A. Lents, F. J White, and D. H. Keisler. 2003. Influence of body condition at calving and postpartum nutrition on endocrine function and reproductive performance of primiparous beef cows. J. Anim. Sci. 81:3107-3120.

Cooke, N. E., and J. G. Haddad. 1989. Vitamin D binding protein (Gc-globulin). Endocr. Rev. 10:294-307.

Cummins, S. B., P. Lonergan, A. C. O. Evans, D. P. Berry, R. D Evans, and S. T. Butler. 2012. Genetic merit for fertility traits in Holstein cows: I. Production characteristics and reproductive efficiency in a pasture-based system. J. Dairy Sci. 95:1310-1322.

Edmonson, A. J., L. J. Lean, L. D. Weaver, T. Farver, and G. Webster 1989. A body condition scoring chart for Holstein dairy cows. J. Dairy Sci. 72:68-78.

Elmlinger, M. W., M. Zwirner, and W. Kuhnel. 2005. Stability of insulin- like growth factor (IGF)-I and IGF binding protein (IGFBP)-3 measured by the IMMULITE automated chemiluminescence assay system in different blood specimens. Clin. Lab. 51:145-152.

Falkenberg, U., J. Haertel, K. Rotter, M. Iwersen, G. Arndt, and W. Heuwieser. 2008. Relationships between the concentration of insulin-like growth factor-1 in serum in dairy cows in early lactation and reproductive performance and milk yield. J. Dairy Sci. 91:3862-3868

Fenwick, M. A., S. Llewellyn, R. Fitzpatrick, D. A. Kenny, J. J. Murphy, J. Patton, and D. C. Wathes. 2008. Negative energy balance in dairy cows is associated with specific changes in IGF-binding protein expression in the oviduct. Reproduction 135:63-75.

Grimard, B., B. Marquant-Lequienne, D. Remy, C. Richard, F. Nuttinck, P. Humblot, and A. A. Ponter. 2013. Postpartum variations of plasma IGF and IGFBPs, oocyte production and quality in dairy cows: Relationships with parity and subsequent fertility. Reprod. Domest. Anim. 48:183-194

Grochowska, R., P. Sorensen, L. Zwierzchowski, M. Snochowski, and P. Lovendahl. 2001. Genetic variation in stimulated GH release and in IGF-I of young dairy cattle and their associations with the leucine/valine polymorphism in the GH gene. J. Anim. Sci. 79:470-476.

Hayhurst, C., A. P. F. Flint, P. Løvendahl, J. A. Woolliams, and M. D. Royal. 2009. Genetic variation of metabolite and hormone concentration in UK Holstein-Friesian calves and the genetic relationship with economically important traits. J. Dairy Sci. 92:4001-4007.

Huang, W., B. S. Yandell, and H. Khatib. 2010. Transcriptomic profiling of bovine IVF embryos revealed candidate genes and pathways involved in early embryonic development. BMC Genomics 11:23.

Jiang, H., and M. C. Lucy. 2001. Variants of the $5^{\prime}$-untranslated region of the bovine growth hormone receptor mRNA: Isolation, expression and effects on translational efficiency. Gene 265:45-53.

Kawashima, C., M. Sakaguchi, T. Suzuki, Y. Sasamoto, Y. Takahashi, M. Matsui, and A. Miyamoto. 2007. Metabolic profiles in ovulatory and anovulatory primiparous dairy cows during the first follicular wave postpartum. J. Reprod. Dev. 53:113-120.

Kerr, D. E., B. Laarveld, M. I. Fehr, and J. G. Manns. 1991. Profiles of serum IGF-I concentrations in calves from birth to eighteen months of age and in cows throughout the lactation cycle. Can. J. Anim. Sci. 71:695-705.

Killeen, A. P., D. G. Morris, D. A. Kenny, M. P. Mullen, M. G. Diskin, and S. M. Waters. 2014. Global gene expression in endometrium of high and low fertility heifers during the mid-luteal phase of the estrous cycle. BMC Genomics 15:234.

Kobayashi, Y., C. K. Boyd, C. J. Bracken, W. R. Lamberson, D. H Keisler, and M. C. Lucy. 1999. Reduced growth hormone receptor
(GHR) messenger ribonucleic acid in liver of periparturient cattle is caused by a specific down-regulation of GHR 1A that is associated with decreased insulin-like growth factor I. Endocrinology 140:3947-3954.

Lammers, B. P., A. J. Heinrichs, and R. S. Kensinger. 1999. The effects of accelerated growth rates and estrogen implants in prepubertal Holstein heifers on growth, feed efficiency, and blood parameters. J. Dairy Sci. 82:1746-1752.

Lucy, M. C., J. Beck, C. R. Staples, H. H. Head, R. L. De La Sota, and W. W. Thatcher. 1992. Follicular dynamics, plasma metabolites, hormones and insulin-like growth factor I (IGF-I) in lactating cows with positive or negative energy balance during the preovulatory period. Reprod. Nutr. Dev. 32:331-341.

Lucy, M. C., H. Jiang, and Y. Kobayashi. 2001. Changes in the somatotrophic axis associated with the initiation of lactation. J. Dairy Sci. 84:E113-E119.

Luk, J., S. Torrealday, G. N. Perry, and L. Pal. 2012. Relevance of vitamin D in reproduction. Hum. Reprod. 27:3015-3027.

Lund, P. K., B. M. Moats-Staats, M. A. Hynes, J. G. Simmons, M. Jansen, A. J. D'Ercole, and J. J. Van Wyk. 1986. Somatomedin$\mathrm{C} /$ insulin-like growth factor-I and insulin-like growth factor-II mRNAs in rat fetal and adult tissues. J. Biol. Chem. 261:14539 14544.

McGuire, M. A., D. E. Bauman, W. S. Cohick, and D. A. Dwyer. 1995. Nutritional modulation of the somatotropin/insulin-like growth factor system: Response to feed deprivation in lactating cows. J. Nutr. 125:493-502.

Meikle, A., M. Kulcsar, Y. Chilliard, H. Febel, C. Delavaud, D. Cavestany, and P. Chilibroste. 2004. Effects of parity and body condition at parturition on endocrine and reproductive parameters of the cow. Reproduction 127:727-737.

Minozzi, G., E. L. Nicolazzi, A. Stella, S. Biffani, R. Negrini, B. Lazzari, P. Ajmone-Marsan, and J. L. Williams. 2013. Genome wide analysis of fertility and production traits in Italian Holstein cattle. PLoS One 8:e80219.

Minten, M. A., T. R. Bilby, R. G. S. Bruno, C. C. Allen, C. A. Madsen, Z. Wang, J. E. Sawyer, A. Tibary, H. L. Neibergs, T. W. Geary, S. Bauersachs, and T. E. Spencer. 2013. Effects of fertility on gene expression and function of the bovine endometrium. PLoS One 8:e69444.

Moore, S. G., T. Fair, P. Lonergan, and S. T. Butler. 2014. Genetic merit for fertility traits in Holstein cows: IV. Transition period, uterine health, and resumption of cyclicity. J. Dairy Sci. 97:27402752

Moyes, T. E. 2004. Variation in concentrations of insulin-like growth factor-1 in pasture-fed Holstein-Friesian cows. PhD Thesis. Department of Veterinary Science, The University of Melbourne, Parkville, Victoria, Australia.

Mullen, M. P., D. P. Berry, D. J. Howard, M. G. Diskin, C. O. Lynch, L. Giblin, D. A. Kenny, D. A. Magee, K. G. Meade, and S. M. Waters. 2011. Single nucleotide polymorphisms in the insulin-like growth factor 1 (IGF-1) gene are associated with performance in Holstein-Friesian dairy cattle. Front. Genet. 2:3.

Nicolini, P., M. Carriquiry, and A. Meikle. 2013. A polymorphism in the insulin-like growth factor 1 gene is associated with postpartum resumption of ovarian cyclicity in Holstein-Friesian cows under grazing conditions. Acta Vet. Scand. 55:11.

NRC. 2001. Nutrient Requirements of Dairy Cattle. 7th ed. Natl Acad. Press, Washington, DC.

Patton, J., D. A. Kenny, S. McNamara, J. F. Mee, F. P. O'Mara M. G. Diskin, and J. J. Murphy. 2007. Relationships among milk production, energy balance, plasma analytes, and reproduction in Holstein-Friesian cows. J. Dairy Sci. 90:649-658.

Purcell, S., B. Neale, K. Todd-Brown, L. Thomas, M. A. Ferreira, D Bender, J. Maller, P. Sklar, P. I. De Bakker, and M. J. Daly. 2007. PLINK: A tool set for whole-genome association and populationbased linkage analyses. Am. J. Hum. Genet. 81:559-575.

Pushpakumara, P. G. A., N. H. Gardner, C. K. Reynolds, D. E Beever, and D. C. Wathes. 2003. Relationships between transition period diet, metabolic parameters and fertility in lactating dairy cows. Theriogenology 60:1165-1185. 
Pushpakumara, P. G. A., R. S. Robinson, K. J. Demmers, G. E. Mann, K. D. Sinclair, R. Webb, and D. C. Wathes. 2002. Expression of the insulin like growth factor (IGF) system in the bovine oviduct at estrus and during early pregnancy. Reproduction 123:859-868.

Rechler, M. M., and S. P. Nissley. 1990. Insulin-like growth factors. Pages 263-267 in Peptide Growth Factors and Their Receptors. 95th ed. M. B. Sporn and A. B. Roberts, ed. Springer-Verlag, Heidelberg, Austria.

Renaville, R., M. Hammadi, and D. Portetelle. 2002. Role of the somatotropic axis in the mammalian metabolism. Domest. Anim. Endocrinol. 23:351-360.

Robinson, R. S., G. E. Mann, T. S. Gadd, G. E. Lamming, and D. C. Wathes. 2000. The expression of the IGF system in the bovine uterus throughout the oestrous cycle and early pregnancy. J. Endocrinol. 165:231-243.

Sargolzaei, M., J. P. Chesnais, and F. S. Schenkel. 2014. A new approach for efficient genotype imputation using information from relatives. BMC Genomics 15:478.

Schneider, A., M. N. Correa, and W. R. Butler. 2013. Association between growth hormone receptor Alul polymorphism and fertility of Holstein cows. Theriogenology 80:1061-1066.

Spicer, L. J., E. Alpizar, and S. E. Ecternkamp. 1993. Effects of insulin, insulin-like growth factor 1 , and gonadotropins on bovine granulosa cell proliferation, progesterone production, estradiol production, and (or) insulin-like growth factor 1 production in vitro. J. Anim. Sci. 71:1232-1241.

Spicer, L. J., W. B. Tucker, and G. D. Adams. 1990. Insulin-like growth factor-I in dairy cows: Relationships among energy balance, body condition, ovarian activity, and estrous behavior. J. Dairy Sci. 73:929-937.

Stirling, T. E., C. R. Stockdale, and K. L. Macmillan. 2008. Heritability of IGF-1 and its genetic correlation with milk yield in HolsteinFriesian cows in selected Victorian herds. Proc. N.Z. Soc. Anim. Prod. 68:98-99.

Swets, J. A. 1988. Measuring the accuracy of diagnostic systems. Science 240:1285-1293.
Taylor, V. J., Z. Cheng, P. G. Pushpakumara, D. E. Beever, and D. C. Wathes. 2004. Relationships between the plasma concentrations of insulin-like growth factor-1 in dairy cows and their fertility and milk yield. Vet. Rec. 155:583-588.

Uehara, Y., O. Minowa, C. Mori, K. Shiota, J. Kuno, T. Noda, and N. Kitamura. 1995. Placental defect and embryonic lethality in mice lacking hepatocyte growth factor/scatter factor. Nature 373:702705

Velazquez, M. A., L. J. Spicer, and D. C. Wathes. 2008. The role of endocrine insulin-like growth factor-I (IGF-I) in female bovine reproduction. Domest. Anim. Endocrinol. 35:325-342.

Wathes, D. C., Z. Cheng, N. Bourne, V. J. Taylor, M. P. Coffey, and S. Brotherstone. 2007. Differences between primiparous and multiparous dairy cows in the inter-relationships between metabolic traits, milk yield and body condition score in the periparturient period. Domest. Anim. Endocrinol. 33:203-225.

Wathes, D. C., T. S. Reynolds, R. S. Robinson, and K. R. Stevenson. 1998. Role of the insulin-like growth factor system in uterine function and placental development in ruminants. J. Dairy Sci. 81:1778-1789.

Wathes, D. C., V. J. Taylor, Z. Cheng, and G. E. Mann. 2003. Follicle growth, corpus luteum function and their effects on embryo development in postpartum dairy cows. Reprod. Suppl. 61:219-237.

Yang, J., S. H. Lee, M. E. Goddard, and P. M. Visscher. 2011. GCTA: A tool for genome-wide complex trait analysis. Am. J. Hum. Genet. $88: 76-82$

Yang, J., N. A. Zaitlen, M. E. Goddard, P. M. Visscher, and A. L. Price. 2014. Mixed model association methods: Advantages and pitfalls. Nat. Genet. 46:100-106.

Young, B. A. 1981. Cold stress as it affects animal production. J. Anim. Sci. 52:154-163.

Zulu, V. C., N. Toshihiko, and Y. Sawamukai. 2002. Insulin-like growth factor 1 as a possible hormonal mediator of nutritional regulation of reproduction in cattle. J. Vet. Med. Sci. 64:657-665. 